\title{
SISTEM SOCIAL DISTANCING BRACELET UNTUK ALERT WARNING SYSTEM (AWS) PENANGGANAAN DAN MITIGASI PADEMIK COVID-19 BERBASIS INTERNET OF THINGS (IOT)
}

\author{
Oleh: \\ Ari Hendra Wijayanti ${ }^{1}$, Chico Hermanu Brillianto Apribowo ${ }^{2}$, Agus Ramelan ${ }^{2}$ \\ ${ }^{1}$ Rumah Sakit Umum Daerah (RSUD) Kota Surakarta, Surakarta \\ chico@ft.uns.ac.id
}

\begin{abstract}
Abstrak
Physical distancing yang dahulu disebut social distancing, merupakan salah satu langkah pencegahan dan pengendalian infeksi virus Corona dengan menganjurkan setiap orang untuk membatasi kunjungan ke tempat ramai dan kontak langsung dengan orang lain. Ketika menerapkan physical distancing, seseorang tidak diperkenankan untuk berjabat tangan serta menjaga jarak setidaknya satu meter saat berinteraksi dengan orang lain, terutama dengan orang yang sedang sakit atau berisiko tinggi menderita COVID-19. Maka dari itudiusulkanlah Social Distancing Bracelet yang memiliki sensor jarak, GPS, dan tertanam sistem cerdas internet of things (IoT). Tujuan kegiatan PKM ini adalah menghasilkan teknologi tepat guna berupa sistem physical distancing bracelet untuk alert warning system (AWS), penanganan, dan mitigasi pademik covid-19 berbasis loT. Dalam kegiatan PKM ini digunakan metode berupa: Studi literatur, perancangan dan simulasi sistem, pembuatan hardware dan program, implementasi, Analisa data, pelaporan dan evaluasi. Prototipe gelang social distancing telah dibuat dan dilakukan pengujian. Gelang menunjukkan fungsi sesuai dengan spesifikasi yang diinginkan yaitu mampu mendeteksi keberadaan orang di sekitar dengan jarak kurang dari 2 meter, mengirimkan posisi pengguna saat ini, dan dapat dilakukan pemantauan pengguna melalui aplikasi android. Alat telah diujicobakan pada masyarakat dan mendapatkan respon yan baik.
\end{abstract}

Kata Kunci: covid-19, Gelang, Physical Distancing, IoT

\begin{abstract}
Physical distancing, which used to be called social distancing, is one of the steps to prevent and control Corona virus infection by encouraging everyone to limit visits to crowded places and direct contact with other people. When implementing physical distancing, a person is not allowed to shake hands and maintain a distance of at least one meter when interacting with other people, especially with people who are sick or at high risk of suffering from COVID-19. Therefore, the Social Distancing Bracelet has been proposed which has a PIR sensor, GPS, and an embedded internet of things (IoT) intelligent system. The purpose of this PKM activity is to produce appropriate technology in the form of a physical distancing bracelet system for an alert warning system (AWS), handling, and mitigating the loT-based COVID-19 pandemic. In this PKM activity, methods are used in the form of: Literature study, system design and simulation, hardware and program creation, implementation, data analysis, reporting and evaluation. The prototype of the social distancing bracelet has been made and tested. The bracelet shows the function according to the desired specifications, which is able to detect the presence of people around with a distance of less than 2 meters, sends the user's current position, and can be monitored by the user through the android application. The tool has been tested on the community and got a good response.
\end{abstract}

Keywords: covid-19, bracellet, Physical Distancing, IoT

\section{PENDAHULUAN}

Wabah virus COVID-19 (Corona) semakin lama semakin berkembang dan meresahkan masyarakat dunia. Hal ini dikarenakan virus ini sangat mudah sekali dalam penyebarannya. World Health Organization (WHO) mengungkapkan, dimana cara penyebaran covid-19 melalui tetesan kecil air liur yang keluar dari hidung atau mulut ketika orang yang terinfeksi virus corona bersin atau batuk. Tetesan itu kemudian mendarat di sebuah benda atau permukaan yang disentuh orang sehat. Setelah orang sehat tersebut menyentuh mata, hidung, atau mulut mereka, Coronavirus akan menginfeksi sistem pernapasan mereka. Pada sebagian besar kasus, coronavirus hanya menyebabkan infeksi pernapasan ringan sampai sedang, seperti flu. Akan tetapi, virus ini juga bisa menyebabkan infeksi pernapasan berat, seperti pneumonia, Middle-East Respiratory Syndrome (MERS), dan Severe Acute Respiratory Syndrome (SARS). Sampai saat ini, belum ada 
vaksin yang cukup efektif untuk mencegah infeksi virus Corona atau COVID-19.

Cara pencegahan yang terbaik adalah dengan menghindari faktor-faktor yang bisa menyebabkan terinfeksi virus ini dengan mengikuti protocolprotokol Kesehatan berupa: penerapan Physical Distancing, menggunakan masker saat beraktivitas di tempat umum atau keramaian, rutin mencuci tangan dengan air dan sabun atau hand sanitizer setelah beraktivitas di luar rumah atau di tempat umum. Juru bicara Pemerintah untuk Penanganan Covid-19 Achmad Yurianto mengatakan ancaman terbesar penyebaran virus corona adalah melalui orang tanpa gejala (OTG) yang mungkin berada di sekitar kita. Oleh sebab itu, Achmad Yurianto mengimbau masyarakat untuk tetap menjaga jarak aman dengan orang lain dan tetap berada di rumah.

Physical distancing yang dahulu disebut social distancing, merupakan salah satu langkah keselamatan penting yang direkomendasikan ( $T$. N. A. Reddy, 2020). Physical distancing merupakan pencegahan dan pengendalian infeksi virus Corona dengan menganjurkan orang sehat untuk membatasi kunjungan ke tempat ramai dan kontak langsung dengan orang lain. Ketika menerapkan physical distancing, seseorang tidak diperkenankan untuk berjabat tangan serta menjaga jarak setidaknya 1 meter saat berinteraksi dengan orang lain, terutama dengan orang yang sedang sakit atau berisiko tinggi menderita COVID-19. Sedangkan WHO menyarankan dua meter adalah jarak aman untuk bisa mengontrol penyebaran virus corona $(\mathrm{H}$. Ugail et al, 2020).

Berdasarkan permasalahan tersebut, dalam kegiatan PKM ini diusulkan pembuatan sebuah prototipe Social Distancing Bracelet yang memiliki sensor jarak, GPS, dan tertanam sistem cerdas internet of things (IoT). Tujuan kegiatan PKM ini adalah menghasilkan teknologi tepat guna berupa sistem physical distancing bracelet untuk alert warning system (AWS), penanganan, dan mitigasi pademik covid-19 berbasis loT. Alat ini mampu mendeteksi obyek lain yang berdekatan dan memberikan sinyal berupa bunyi, dan didukung dengan sistem loT sehingga mempermudah pengguna dalam memonitoring jarak dan lokasi kapanpun dan dimanapun. Dengan adanya prototipe alat ini, diharapkan masyarakat lebih memperhatikan dan menerapkan Physical Distancing terutama bagi masyarakat yang terpaksa keluar rumah karena keperluan mendesak.

\section{METODE}

Metode yang digunakan dalam kegiatan PKM ini adalah:

1. Studi Literatur

Setelah mengidentifikasi masalah, dilakukan pencarian sumber-sumber referensi berupa jurnal, paper, artikel, dan sumber dalam bentuk lain yang berkaitan dengan masalah yang ada. Kemudian melakukan desain perancangan alat sebagaimana alat ini dapat memecahkan permasalahan yang ada.

2. Perancangan dan Simulasi Sistem

Dilakukan perancangan hardware dan algoritma sistem sesuai dengan kebutuhan untuk memberikan solusi dari permasalahan yang ada. Dilakuakn simulasi sistem untuk mengetahui keberhasilan dari sistem sebelum direalisasikan

Gambar 2 menunjukan gambaran alat yang terdiri dari beberpaa komponen utama yaitu: NodeMCU, sensor PIR, dan Buzzer.

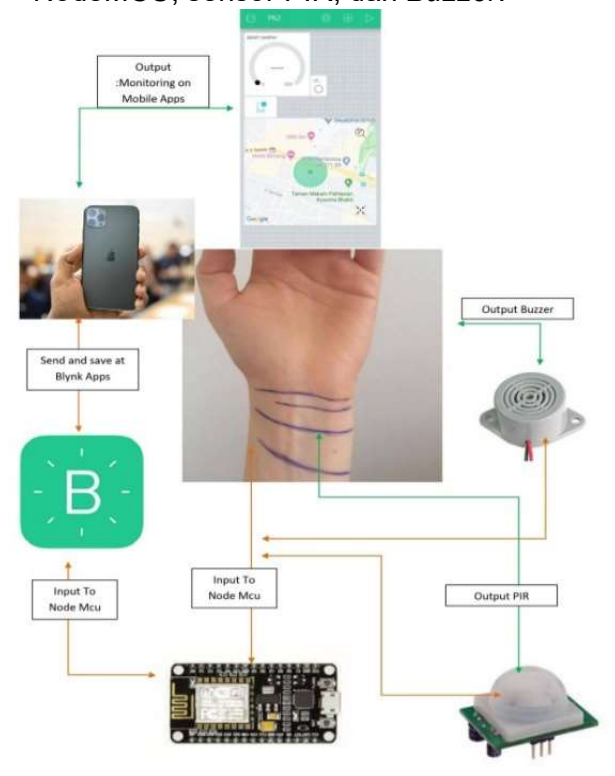

Gambar 2. Gambaran Alat

3. Pembuatan Hardware dan Program

Pembuatan hardware dan program berdasarkan simulasi yang telah berhasil. Sistem yang telah dibuat kemudian diuji dan dilakukan evaluasi apabila belum bekerja sesuai dengan yang diharapkan.

4. Implementasi

Implementasi dilakukan dengan menggunakan gelang social distancing pada beberapa sukarelawan. Dilakukan juga pengambilan data terkait kemampuan hardware dalam mendeteksi manusia dan kemampuan alat dalam beroperasi, dalam beberapa repetisi kemudian dilakukan ratarata.

5. Analisa Data

Dilakukan Analisa data bagaimana kinerja dari gelang social distancing. Bagaimana gelang dapat memberikan peringatan dan melakukan pencarian lokasi.

6. Pelaporan dan Evaluasi

Pada tahap ini dilakukan pelaporan kegiatan PKM dan evaluasi untuk ke depan. 


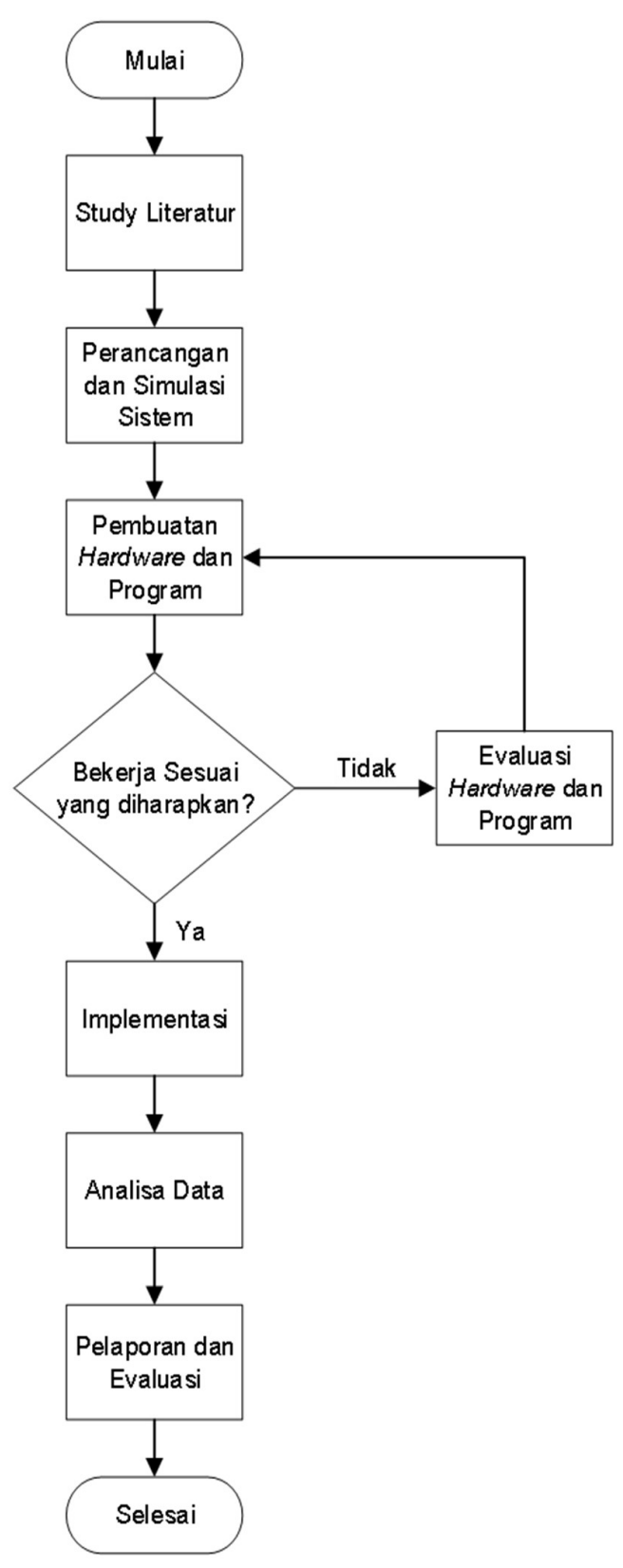

Gambar 1. Diagram Alir Metode Kegiatan PKM

\section{HASIL DAN PEMBAHASAN}

A. Hasil Kegiatan dan Pembahasan

a) Pembuatan Hardware dan Aplikasi

Gelang social distancing terdiri dari hardware dan aplikasi di Android. Berikut adalah foto alat dan tampilan aplikasi di Android.

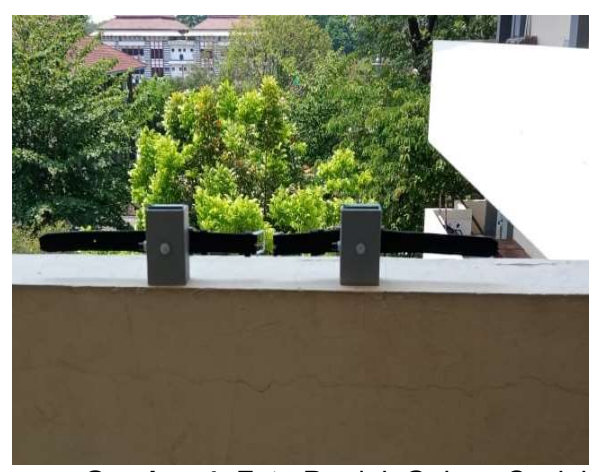

Gambar 4. Foto Produk Gelang Social Distancing

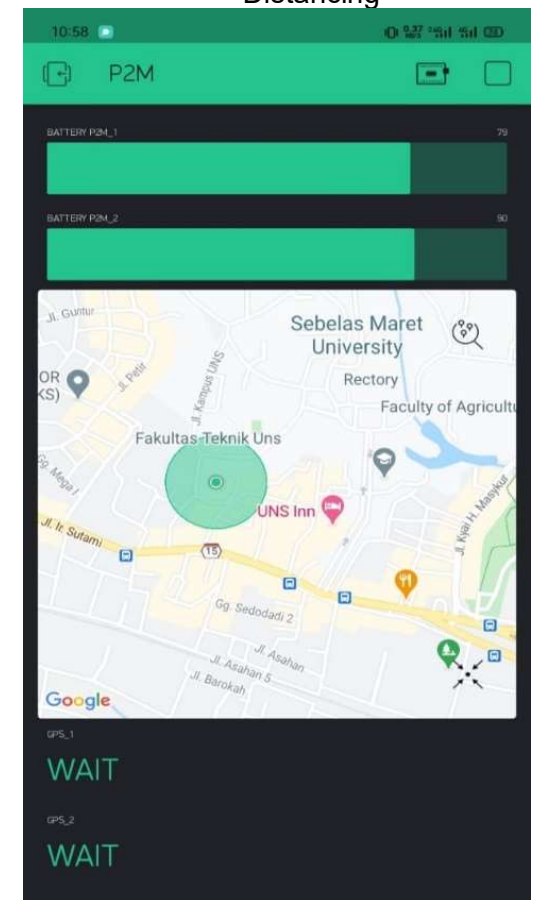

Gambar 4. Tampilan Aplikasi Produk Gelang Social Distancing

Cara Penggunaan Aplikasi

Penggunaan Aplikasi Blynk

1. Download aplikasi Blynk

2. Login pada aplikasi Blynk dengan

3. Pilih pada projek $\mathrm{P} 2 \mathrm{M}$

4. Tekan tombol play pada pojok kanan atas

Pengunaan Gelang

a. Kaitkan strap gelang pada pergelangan tangan seperti memakai jam pada umumnya

b. Tekan tombol switch pada gelang.

c. Buka aplikasi blynk

d. Tunggu beberapa saat hingga gelang terkoneksi dengan aplikasi(ditandai dengan adanya tulisan connected di bagian bawah kiri atau dengan melihat status koneksi dengan menekan gambar mikrokontroler di bagian kanan atas) 


\section{b) Pengisian Ulang}

Gelang dapat bekerja hingga waktu \pm 1 jam. Ketika koneksi pada aplikasi Blynk mulai terputus, hal ini mengindikasikan baterai mulai melemah. Baterai akan benar benar habis, ketika koneksi dengan aplikasi Blynk terputus dan buzzer tidak berbunyi lagi. Untuk melakukan proses pengisian ulang, dapat dilakukan dengan langkah berikut:

a. Mematikan gelang dengan menekan tombol switch

b. Memasangkan charger ke port pengisian gelang

c. Tunggu hingga 30 menit, kemudian lepas charger atau

d. Tunggu hingga 30 menit, kemudian nyalakan gelang, cek kondisi baterai pada aplikasi blynk, bila indicator telah menunjukan 100, maka baterai telah terisi penuh.

\section{c) Pengujian}

Pengujian dilakukan untuk mengetahui peforma dari alat. Secara teknis, hasil pengujian menghasilkan spesifikasi alat sebagai berikut.

- Waktu untuk dapat terkoneksi dengan aplikasi (kecepatan koneksi dipengaruhi oleh lokasi, uji coba dilakukan di desa sroyo, jaten, kebakkeramat) yaiut 41.3 detik.

- Waktu untuk dapat mendeteksi lokasi (kecepatan pencarian lokasi dipengaruhi oleh lokasi, uji coba dilakukan di desa sroyo, jaten, kebakkeramat) yaitu 5.7 menit.

- Jarak deteksi sensor $\pm 2 \mathrm{~m}$ dengan gerakan normal

- Radius deteksi sensor up to $180^{\circ}$

- $\quad$ Charging Time (dari $3.2 \mathrm{~V}$ atau $0 \%$ sampai 4.2 $V$ atau $100 \%) \pm 30$ menit.

- Working Time \pm 1 jam.

Pengujian juga dilakukan dengan dua orang pengguna, di mana hasilnya gelang mendeteksi pergerakan orang jika jarak nya kurang dari 2 meter.

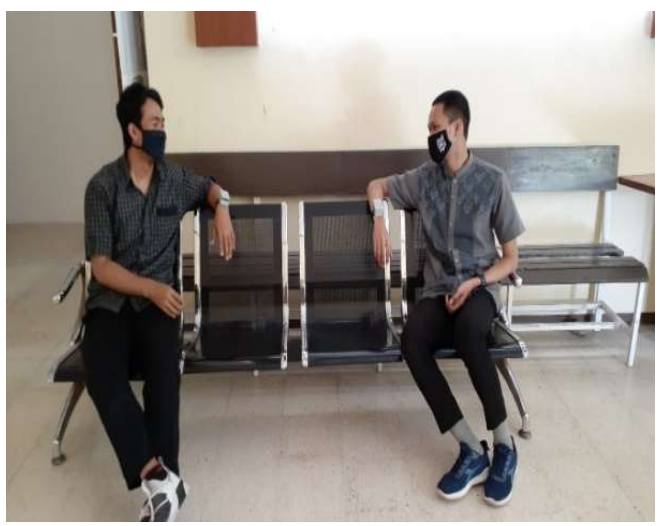

Gambar 5. Tampilan Aplikasi Produk Gelang Social Distancing

\section{SIMPULAN DAN SARAN}

\section{Simpulan}

Dari kegiatan yang telah dilakukan dapat disimpulkan bahwa alat social distancing bracelet telah berhasil dibuat dan diuji cobakan di masyarakat. Masyarakat merespon alat ini dengan baik.

\section{Saran}

Dalam pelaksanaan kegiatan ini perlu dilakukan perbaikan, seperti proses edukasi dan pengenalan alat kepada masyarakat.

Dalam pelaksanaan kegiatan ini perlu dilakukan perbaikan, seperti proses edukasi dan pengenalan alat kepada masyarakat.

Dari kegiatan yang telah dilakukan dapat disimpulkan bahwa alat social distancing bracelet telah berhasil dibuat dan diuji cobakan di

\section{DAFTAR PUSTAKA}

Adrian, Kevin.2020. Pentingnya Menerapkan Physical Distancing Demi Mencegah Covid19. https://www.alodokter.com/pentingnyamenerapkan-physical-distancing-demi-

mencegah-covid-19

Diakses pada tanggal 14 April 2020

Anonim.2020. Ingat! Begini Cara Penyebaran Virus Corona Versi WHO. https://www.cnbcindonesia.com/tech/20200406 085228-37-149920/ingat-begini-carapenyebaran-virus-corona-versi-who Diakses pada tanggal 14 April 2020

Anonim. Apa Itu Modul ESP8266 http://www.nyebarilmu.com/mengenal-aplikasiblynk-untuk-fungsi-iot/ Diakses pada tanggal 02 April 2020

Anonim. Mengenal aplikasi BLYNK untuk fungsi IOT https://www.nyebarilmu.com/mengenalaplikasi-blynk-utuk-fungsi-iot/ Diakses pada tanggal 02 April 202

Anonim. PENGERTIAN SENSOR PASSIVE INFRA RED DAN CARA KERJANYA

https://www.immersa-lab.com/pengertiansensor-passive-infra-red-dan-carakerjanya.htm

Diakses pada tanggal 02 April 2020

Dame, Merry.2020. Virus Corona ( COVID-

19).https://www.alodokter.com/virus-corona Diakses pada tanggal 14 April 2020

Fahreza, Aji. Menggunakan Buzzer Komponen Suara https://www.ajifahreza.com/2017/04/mengguna kan-buzzer-komponen-suara.html Diakses pada tanggal 02 April 2020

H. Ugail et al., "On Rearranging Physical Spaces for Enhancing Social Distancing Measures to Combat the COVID-19 Infection Rates," 2020 Int. Conf. Internet Things Intell. Appl. ITIA 2020 , 2020 ,

doi: 10.1109/ITIA50152.2020.9312322.

Nuraini, Nuning, Kamal Khairudin, and Mochamad Apri.2020. "Data dan Simulasi COVID-19 
dipandang dari Pendekatan Model Matematika." Preprint.

T. N. A. Reddy, "Social Distance Alert System to Control Virus Spread using UWB RTLS in Corporate Environments," pp. 0-5, 2021.

Telaumbanua, Dalinama.2020. "Urgensi Pembentukan Aturan Terkait Pencegahan Covid-19 di Indonesia." QALAMUNA: Jurnal Pendidikan, Sosial, dan Agama 12.01 (2020): 59-70.

World Health Organization. "Coronavirus disease 2019 (COVID-19): situation report, 72." (2020).

Yudhanto, Yudha.2015. Apa itu IoT (Internet of Thing). Surakarta 